\title{
Forty years of European Society for Muscle Research
}

\author{
Marcus C. Schaub \\ Institute of Pharmacology and Toxicology, University of Zurich, Switzerland
}

\begin{abstract}
The European Muscle Club was founded 1971 and since 1972 yearly muscle conferences were held in turn in different European countries. Regular scientific meetings in the field of muscle research did not exist before. The name of the Muscle Club was 1988 changed to European Society for Muscle Research (ESMR). The yearly meetings usually attract 200-300 participants. The 39th meeting will be held 11-15 Sept. 2010 in Abano Terme near Padova, and the 40th meeting 14-18 Sept. 2011 in Berlin. Since 1980 the meeting reports and abstracts are regularly published in the Journal of Muscle Research and Cell Motility (JMRCM). The history of the society and the muscle scientists involved with it will be outlined.
\end{abstract}

Key Words: European Muscle Club, European muscle society, European muscle conference, Muscle research in Europe, British muscle dining club

European Journal Translational Myology - Myology Reviews 20101 (3): 77-82

1. The European Muscle Club's ancestor

2. The way to the European Muscle Club

3. Transition from Muscle Club to European Society of Muscle Research

4. European Muscle Conferences

5. The Muscle Club's three Children

6. ESMR membership and Raison d'être

7. Acknowledgments and Outlook

The European Society for Muscle Research (ESMR) will hold its 39th EMC (European Muscle Conference) from 11-15 September 2010 in Abano Terme near Padova organized by Carlo Reggiani (University of Padova) and Marco Sandri (Venetian Institute of Molecular Medicine, Padova). This implies there were before another 38 EMC meetings in different European countries (Table 1) testifying to the success and constancy of the ESMR whose major purpose is to hold yearly meetings on muscle research of high scientific standard [8]. The meeting in Padova brings the number of EMC in Italy to a total of 6 . This equals the number of meetings held in Germany during the past. This brief survey tracks the development of the muscle society over the past 40 years.

\section{The European Muscle Club's ancestor}

As may be guessed from their names, the British muscle dining club had some bearing on the emergence of the European muscle club. The connection does not solely derive from the common term "club", indicative of informal organizations, but as much from the common topic of muscle research presenting the prime purpose of both clubs. Over much of the last century, Britain was (and still is) a stronghold in muscle research, earlier in physiology and later in subcellular structure and biochemistry. In the fifties two classic papers in one single issue of Nature by A. F. Huxley and Niedergerke [3], and by H. E. Huxley and Hanson [4] established the sliding-filament model for contraction of striated muscle. The attention quickly focused on the origins of force that gives rise to the filament sliding, in particular on the involvement of the actin-myosin cross bridges [1]. Around the same time scientists started to resort to newly developed biochemical technology. Perry (first in Cambridge, later in Birmingham, UK), one of the founding fathers of muscle biochemistry, was conclusively engaged in elucidating the function of the troponin components in striated muscle [6]. I was almost 4 years working in the late sixties with Sam Perry on isolation and characterization of the troponin subunits. It was a great privilege for me to have been introduced by Perry to muscle biochemistry and the halcyon British way of life, as well as to assist in ground breaking research on regulation of muscle contraction $[9,10]$. The combined efforts of mainly the three laboratories of Ebashi (Tokyo), Gergely (Boston), and Perry (Birmingham, UK) led in 1972 at the memorable Cold Spring Harbor Symposium on Muscle Contraction [11] to a general consensus on function and nomenclature of troponin consisting of three functionally different subunits: $\mathrm{TnI}$ (former inhibitory factor or troponin-B), TnC (former $\mathrm{Ca2+-sensitizing} \mathrm{factor} \mathrm{or} \mathrm{troponin-A)} \mathrm{and} \mathrm{TnT}$ 
Forty years of European Society for Muscle Research

European Journal Translational Myology - Myology Reviews 1 (3): 77-82, 2010.

Table 1. Past European Muscle Conferences (EMC) with approximate numbers of participants in the last column

\begin{tabular}{|c|c|c|c|c|}
\hline 1972 & Liège & Belgium & Gabriel Hamoir & 47 \\
\hline 1973 & Lenzburg & Switzerland & Marcus Schaub & 68 \\
\hline 1974 & Budapest & Hungary & Endre Biró & 80 \\
\hline 1975 & Aarhus & Denmark & Jack Lowy & 120 \\
\hline 1976 & Bressanone & Italy & Alfredo Margreth & 160 \\
\hline 1977 & Saclay/Paris & France & Ingrid Pinset-Härström & 110 \\
\hline 1978 & Warszawa & Poland & Witek Drabikowski & 120 \\
\hline 1979 & Heidelberg & Germany & Caspar Rüegg & 220 \\
\hline 1980 & Salzburg & Austria & Vic Small & 235 \\
\hline 1981 & Galway & Ireland & D. R. Headon & 110 \\
\hline 1982 & Leicester & UK & Arthur Rowe, Clive Bagshaw & 210 \\
\hline 1983 & Szeged & Hungary & Ferenc Guba / Ödön Takacs & 180 \\
\hline 1984 & Gwatt & Switzerland & Marcus Schaub & 240 \\
\hline 1985 & Ulm & Germany & Reinhardt Rüdel & 230 \\
\hline 1986 & Montpellier & France & Ridha Kassab & 225 \\
\hline 1987 & Tiberias & Israel & Avraham Oplatka, Benny Geiger & 180 \\
\hline 1988 & Abano Terme & Italy & Ugo Carraro & 210 \\
\hline 1989 & Lunteren & Netherlands & Tugendhold Blangé & 220 \\
\hline 1990 & Brussels & Belgium & Georges Maréchal & 260 \\
\hline 1991 & Oxford & UK & Chris Ashley, Gerald Elliott & 230 \\
\hline 1992 & Bielefeld & Germany & Harald Jockusch, Horst Hinssen & 270 \\
\hline 1993 & Gwatt & Switzerland & Marcus Schaub & 235 \\
\hline 1994 & Bochum & Germany & Ludwig Heilmeyer & 220 \\
\hline 1995 & Firenze & Italy & G. Cecchi, F. Colombo, C. Poggesi & 300 \\
\hline 1996 & Montpellier & France & Tom Barman, Franc Travers & 240 \\
\hline 1997 & Hannover & Germany & Bernhard Brenner & 190 \\
\hline 1998 & Lund & Sweden & Anders Arner, Per Hellstrand & 226 \\
\hline 1999 & York & UK & John Sparrow, Justin Molloy & 216 \\
\hline 2000 & Berlin & Germany & Ingo Morano & 195 \\
\hline 2001 & Pavia & Italy & Roberto Bottinelli, Carlo Reggiani & 250 \\
\hline 2002 & Lunteren & Netherlands & Ger Stienen & 180 \\
\hline 2003 & Montpellier & France & Patrick Chaussepied, Michel Pucéat & 340 \\
\hline 2004 & Isola d'Elba & Italy & Vincenzo Lombardi & 270 \\
\hline 2005 & Debrecen & Hungary & István Jóna & 170 \\
\hline 2006 & Heidelberg & Germany & Rainer Fink & 220 \\
\hline 2007 & Stockholm & Sweden & Anders Arner, Lars Larsson & 240 \\
\hline 2008 & Oxford & UK & Steven Marston, Charles Redwood & 230 \\
\hline 2009 & Lille & France & Bruno Bastide, Laurence Stevens & 160 \\
\hline 2010 & Padova & Italy & Carlo Reggiani, Marco Sandri & ??? \\
\hline 2011 & Berlin & Germany & Ingo Morano & ??? \\
\hline
\end{tabular}

Table modified from reference [8].

(anchoring the troponin components to tropomyosin). To our great sorrow Perry died last December 2009 at the age of 90 , with him a great muscle scientist is gone. During the sixties, a muscle dining-club grew up and was cultivated by holding dinners in turn, once every six months or so, in the different centers where muscle laboratories were located: Oxford, Cambridge, Birmingham and London. Perry took me along to these informal meetings aiming for contacts and exchange of ideas between muscle scientists in the UK $[1,6]$. Occasionally, though not always, a formal lecture was given, but an important factor was the food and the wine served. On my return to Switzerland, I was missing such occasions to meet with muscle scientists on the Continent. Certainly, there were many laboratories working on muscle, but geographically dispersed between Scandinavian countries in the North and Italy in the South, as well as between Russia (former Soviet Union) in the East and France in the West. Informal muscle dinner with long journeys for one evening was no option.

\section{The way to the European Muscle Club}

Back on the Continent, during 1971 I contacted friends including Caspar Rüegg (Heidelberg), Jean Légér and Bernard Swynghedauw (Paris), Georges Maréchal (Brussels), Gabriel Hamoir (Liège), Edi Jenny and Ruedi Billeter (Zurich), Endre Biró (Budapest), in order to gather momentum for launching the European Muscle Club (EMC) modeled along the lines of the British forerunner. The plan was, however, 
Forty years of European Society for Muscle Research

European Journal Translational Myology - Myology Reviews 1 (3): 77-82, 2010.

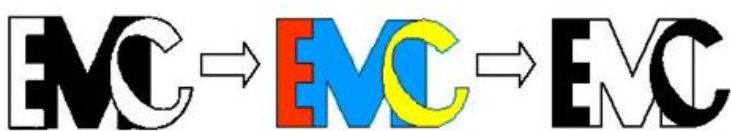

Fig. 1 Transitions of the EMC logo originally standing for "European Muscle Club" and since the "Club" has mutated to "Society", it stands for "European Muscle Conference". After ref. [8].

to hold yearly muscle conferences in a different European country lasting for several days instead of an evening dinner. At that time, no regular meetings on muscle research were held on the European continent. The first EMC meeting took place in 1972 under the auspices of the late Gabriel Hamoir in Liège (Belgium). This dates well back into the pre-computer era where history meets the misty dawn of the EMC. Records may be holey and some details have been forgotten altogether.

From memory I recall that 47 participants gathered at the Liege -1972 EMC. Beside muscle science one of the main endeavors was the official establishment of the Muscle Club. A heated debate flared up in search for a name. "Continental Muscle Club" was favored over "European Muscle Club". To be frank, first, we were not sure whether the British will think it worth to cross the Channel for joining us in future meetings, and second, some Continentals were afraid to become overpowered and dominated by the British stronghold in muscle research [8]. Together with several colleagues I was strongly opting for the unifying term "European Muscle Club", and fortunately this was finally adopted. During subsequent years more and more British muscle researchers used to participate in the EMC meetings. It may be said without scruples that the EMC was instrumental in bringing muscle researchers from different laboratories and different European countries together and was thus helping to induce collaborations. Over the years the scientific quality of the meetings has significantly improved. One wonders whether the improved scientific standard began to attract the British muscle scientists to join the meetings, or whether the British contributions raised the scientific standard on the Continent. It does look, however, as if both sides would have contributed their share. In any case, Table 1 tells us that past EMC meetings have already been held four times in Britain.

\section{Transition from Muscle Club to European Society of Muscle Research}

I was leading the EMC with the help of a Committee of 6 to 8 members from 1971 up to 1995 when Ger Stienen from Amsterdam took over followed almost 10 years later by Anders Arner from Stockholm (formerly in Lund) who started the present period.

The Committee Board was preferably composed of club members who had organized former conferences.
But it was also observed to have representatives from the different European countries including those with renowned muscle research laboratories like Italy (the "Fertile Crescent" of Northern Italy with Pavia, Milano, Padova, Firenze); Paris and Montpellier in France; Heidelberg, Konstanz and Bochum in Germany; Brussels (Belgium); Amsterdam (Netherlands); Lund and Stockholm in Sweden; Warsaw (Poland); Sankt Petersburg (former Leningrad) and Moscow in Russia (former Soviet Union till 1991), to name but a few; not forgetting, however, the muscle stronghold in Britain.

We repeatedly asked the members whether we should more formalize the society, but the vast majority wanted to keep it as informal as it was. Nevertheless, a number of things have changed since its beginnings. The development of the EMC may be visualized by the modification of the logo with time (Fig. 1): white/black/white mutates into red/blue/yellow and reverts back to black/white/black in reverse order of the original pattern. I designed this logo in the 1970ties and it was used for all meetings ever since. In 2002 with the meeting in Lunteren (Netherlands) Ger Stienen rejuvenated it by adding the colors, and on the Oxford-2008 abstract book it again shines in decent black and white.

How come the "Club" has changed its name to "European Society for Muscle Research"? The "Journal of Muscle Research and Cell Motility" (JMRCM) founded by Richard Tregear and Chris Ashley (Oxford) started in 1980. From then onward the abstracts of the yearly EMC conferences were officially published in the JMRCM. With that the "Club" gained some wider international visibility and started to attract participants from all over the world. By that time, the term "Muscle Club" became a little ill-reputed; I was repeatedly asked by the bank with our account what kind of body building club am I managing. Actually, at the EMC 1985 in Ulm (Germany) the organizer Reinhardt Rüdel invited a group of professional body builders (men and women) who presented a breathtaking performance in applied myology. Perhaps inspired by this fascinating show, a few years later, in 1991, Ugo Carraro (Padova, Italy) started a new muscle journal appropriately called "Basic and Applied Myology" (BAM). With its 20th volume appearing in 2010 BAM changed its name to "European Journal of Translational Myology" and continues to publish original research articles under "Basic Applied Myology" and expert reviews in a second line called "Myology Reviews" (for details see, http://www.bio.unipd.it/bam/bam.html).

As times changed, it got more and more difficult to raise financial support from National Science Foundations and other grant-giving organizations for the "Muscle Club Meetings". Finally, 1988 at the meeting organized by Ugo Carraro (Padova) in Abano 


\section{Forty years of European Society for Muscle Research}

European Journal Translational Myology - Myology Reviews 1 (3): 77-82, 2010.

Terme the name "European Society for Muscle Research" (ESMR) was adopted. The term EMC was kept with its logo as label for the yearly muscle conferences. Ugo Carraro was an early enthusiast of the "Club" and the ESMR. As a young muscle researcher (working with Alfredo Margreth in Padova) he attended most of the EMC meetings beginning with Lenzburg in Switzerland 1973 and served for well over 20 years on the Committee Board.

\section{European Muscle Conferences}

The ESMR was very successful in bringing muscle researchers from various laboratories in different European countries together and inducing many new cooperations, cooperations which did almost not exist in the early seventies of last century among the Continental muscle community. As summarized in Table 1 , the attendance at the meetings gradually increased over the years, fluctuating between 200 and 300 (which is an ideal size for scientific meetings) since the 1980ties (Table 1). The conferences have always been open not only for the established researchers but also for young and new people in the field. We are particularly proud of the fact that every year about one third of the conferees are new and young scientists joining for the first time. This assures a lively turnover of the meeting community, and it also indicates that many young biologists start their scientific career in research related to muscle. Muscle presents the most promising source for interdisciplinary approaches. Fundamental biological paradigms have surfaced in the past by working on muscle such as signaling pathways, tissue plasticity, and genetics in disease, intracellular calcium-signaling, metabolism, electrophysiology, structure-function relations, and many more. As the conferences are held in turn among the European countries, the main topics of the individual meetings are shifting from year to year according to the research focus of the local organizers. This also entails some rotation among the participants that prevents the yearly institution from becoming merely routine.

From its very beginning the "Muscle Club" had strong connections to the Eastern European countries beyond the Iron Curtain (in operation from 1945 till 1991). It was our policy to help the muscle scientists from the East by supporting them financially for attendance of our Conferences. This brought me in contact with muscle research institutes and governmental offices in these Eastern countries. Many stories could be told about last minute rescue operations when scientists did not know whether they could travel to the West until two days before the conference started. And if they were allowed to leave the Eastern countries, often they got stranded at the entrance in the West with no money left. However, long-lasting friendships originated from such adventurous experiences. For many Eastern scientists it was comforting to have at least an abstract published in a Western scientific journal.

Though this is not the place for scientific accounts, let me allude to three conference highlights. At the second meeting 1973 in Lenzburg (Switzerland) Giulio Gabbiani (Geneva) was telling us that liver and pancreas comprise actin [2]. Most attendants incredulously smiled and did not believe it. At that time actin strictly was a muscle protein and nothing else. Later it was recognized that actin is the most abundant protein in the entire animal kingdom. Ken Holmes (Heidelberg) reported 1990 in Brussels on the newly resolved atomic structure of skeletal muscle actin [5] and Clyde A. Smith described three months after the historic publication [7] in Gwatt (Switzerland) the structure of the myosin head refined to 2.8 Angstrom.

\section{The Muscle Club's three Children}

Another pleasing aspect of the EMC-ESMR arises from its fertility: it has produced three children. The first descendant was 1976 the "Club Francophone du Muscle" mainly comprising the French speaking muscle scientists in France, Belgium, and Switzerland. The purpose was to hold yearly meetings, in addition to the EMC, consequently using only French (English was forbidden) in order to feel at ease in talking and discussing together. I believe after a few years this custom was silently dying out.

The second descendant was a more successful procreation, the "European Cytoskeletal Club". The meeting program got overloaded by the cytoskeletal field which started growing rapidly in the 1970ties. In order to avoid parallel sessions at the meetings the Cytoskeletal Club started its own meeting schedule in 1981 in Nyon (Switzerland) organised by Giulio Gabbiani (Geneva). The original idea was to occasionally hold common meetings of both "Clubs" together. One such common meeting was organized by Avraham Oplatka and Benny Geiger 1987 in Tiberias (Israel), and by Marcus Schaub 1993 in Gwatt (Switzerland). Facing similar problems as our EMC, the "European Cytoskeletal Club" mutated 1990 to the more respectable "European Cytoskeletal Forum", since then known by its acronym ECF.

The third descendant is the "Alternative Muscle Club" (AMC) founded in 1981. Its 28th meeting was held in June 2009 in Manchester. The declared focus of each AMC meeting is on poster sessions and talks from delegates, in a "non-intimidating" environment (hence "alternative"). To me this confession sounds rather familiar, it could as well be derived from the EMCESMR guidelines, and that is what makes them both so agreeable and congenial. Many of the young scientists from the AMC are also frequenting the EMC meetings. When one gets the announcements from the AMC, hesitation for only one second, then ah yes, that's in Britain; of course, the British stronghold in muscle 


\section{Forty years of European Society for Muscle Research}

European Journal Translational Myology - Myology Reviews 1 (3): 77-82, 2010.

research does even not require the country name in its title.

\section{ESMR membership and Raison d'être}

Who may be accepted as ESMR member? Every muscle scientist who attends an EMC conference will automatically become a member by registration on the member address list in order to receive next year's information for the upcoming meeting. A membership fee has never been levied so far. There is a saying: What costs nothing isn't worth it. This seems, however, not to apply to the ESMR as the address list is rather long with around thousand entries, and many scientists are regularly attending the yearly conferences, sometimes pausing depending on the local scientific program. Members who haven't attended meetings for several years in succession will be removed in order to keep the address list manageable.

Since no membership fees have been claimed, the financial side of the ESMR has been kind of precarious during the first three decades. As it became more and more difficult to raise funds for the yearly conferences, it was decided, about ten years ago, to transfer from each conferee's registration between 10 and 20 Euro to the cash box of the ESMR alimenting secretarial work and enabling the Chairman to help the local organizer of the yearly meetings and to offer financial support for young scientists who otherwise could not attend. As a result the ESMR presently holds some cash (between 20 '000 and 30'000 Euro). As a consequence the ESMR will register as a scientific non-profit organization and corresponding statutes have been implemented. So after almost 40 years in existence the ESMR is being transformed from a loose informal "Club" to an established "Society", though by and large the members may not feel any significant changes in the handling of the yearly conferences.

At the Oxford conference 2008 (organized by Steven Marston and Charles Redwood), for the first time, a "Young Investigator Award" has been given to the best oral and poster contributors (around 300 Euro each). This was also the case at last year's Meeting in Lille (organized by Bruno Bastide and Laurence Stevens), and it will be pursued in the future (as long as the finances allow for it, I hasten to add). The award winners are then invited to submit a short review paper about their work for publication in the JMRCM.

This brings me to a last short consideration. In Europe, at least on the Continent, muscle research is eking out a somewhat meager existence in terms of recognition and grant support. Grant applications for research on physiology, biochemistry, cell biology, even on genetics and genomics, often meet with relegation to minor priorities if concerning (only) muscle. That is distressful in view of the massive support being granted to research in neurobiology. As opposed to neurobiology, diabetes, or cardiology, where researchers form coherent scientific communities powerful in pursuing their interests, muscle scientists appear more loosely organized and are disseminated in small groups often affiliated to institutions one would not expect them. Can that be improved? The EMCESMR together with the JMRCM might provide a combined platform that should and could be better exploited for muscle research in Europe. Presumably, we muscle people all like the JMRCM, but seldom publish in it. Its impact factor ranges around 2 , that is not enough; efforts should be taken to bring it up to around 4 in order to have a reasonable impact on the scientific community. Let's try to aim at that mark by submitting high quality reports to JMRCM. A journal is as good as the submitted research papers (but not the other way round). And for that matter, a scientific society is as good as its members and its meetings.

\section{Acknowledgments and Outlook}

The Chairmen, present and past, like to thank the Committee Board and all the conference organizers (who really carried the lion's share of the work) for their unrelenting commitments and efforts over 4 decades as well as the editors of the JMRCM. A lot has been achieved, but we should not sit back, because a great challenge still lies ahead. We are particularly grateful to the young muscle scientists each year joining the EMC; thanks to them he Society is thriving. They muster our hope for the future of muscle research in Europe and beyond.

After this year's meeting in Padua, the 40th conference will be organized by Ingo Morano (Max-DelbrückCenter for Molecular Medicine) in Berlin from 14 to 18 September 2011. The ESMR homepage you find under: http://www.esmr.org/.

\section{Corresponding Author}

Prof. Marcus C. Schaub, MD, PhD, Institute of Pharmacology and Toxicology, University of Zurich, Winterthurerstrasse 190 CH-8057 Zurich, Switzerland Phone: +41 446355919 Fax: +41 446356871

E-mail: schaub@pharma.uzh.ch

\section{References}

[1] Elliott G. Recollections of the British muscle dining club, one origin of the European muscle congress. J Muscle Res Cell Motil 2008; 29: 147149 .

[2] Gabbiani G, Malaisse-Lagae F, Blondel B, Orci L. Actin in pancreatic islet cells. Endocrinology 1974; 95: 1630-1635.

[3] Huxley AF, Niedergerke R. Interference microscopy of living muscle fibres. Nature 1954; 173: 971-973.

[4] Huxley HE Hanson EJ. Changes in the cross striations of muscle during contraction and stretch and their structural interpretation. Nature 1954; 173: 973-976. 


\section{Forty years of European Society for Muscle Research}

European Journal Translational Myology - Myology Reviews 1 (3): 77-82, 2010.

[5] Kabsch W, Mannherz HG, Suck D, Pai EF, Holmes KC. Atomic structure of the actin:DNase I complex. Nature 1990; 347: 37-44.

[6] Perry SV. Fate has smiled kindly. Comprehensive Biochem 1997; 40: 383-462.

[7] Rayment I, Rypniewski WR, Schmidt-Bäse K, Smith R, Tomchick DR, Benning MM, Winkelmann DA, Wesenberg G, Holden HM. Three-dimensional structure of myosin subfragment-1: a molecular motor. Science. 1993; 261: 50-58.

[8] Schaub MC. Footsteps of the European society for muscle research (1971-2008). J Muscle Res Cell Motil 2008; 29: 151-154.
[9] Schaub MC, Perry SV. The regulatory proteins of the myofibril. Characterization and properties of the inhibitory factor (troponin-B). Biochem J 1971; 123: 367-377.

[10] Schaub MC, Perry SV, Häcker W. The regulatory proteins of the myofibril. Characterization and biological activity of the calcium-sensitizing factor (troponin-A). Biochem J 1972; 126: 237249.

[11] The mechanism of muscle contraction. Cold Spring Harbor Symp Quant Biol. Vol. XXXVII, Cold Spring Harbor Laboratory, 1973. 